\title{
Õppetegevuste haaravus, aktiivsus ja jõukohasus eesti keele kui teise keele täiskasvanute kursustel: õpetajate arvamuste analüüs
}

\author{
MARE KITSNIK, KATRIN MIKK \\ Tartu Ülikool \\ Ülevaade. Artiklis vaadeldakse eesti keele kui teise keele õpetajate \\ ( $n=59$ ) vastuseid küsitlusele täiskasvanute kursustel kasutatavate \\ õppetegevuste, õppetöös esinevate probleemide ning heade koge- \\ muste kohta. Õppetegevuste tõhusust analüüsitakse haaravuse, \\ aktiivsuse ja jõukohasuse seisukohalt. Analüüsi põhjal tehakse \\ ettepanekuid õppetegevuste arendamiseks.
}

Võtmesõnad: teise keele õpe; keelekursused; õppetegevused; haaravus; aktiivsus; jõukohasus; eesti keel

\section{Keeleõppe haaravuse, aktiivsuse ja jõukohasuse mõju keeleõppe tõhususele}

Täiskasvanud õpivad eesti keelt teise keelena sageli kursustel, mida korraldavad keelefirmad ja kus valmistutakse riiklike tasemeeksamite sooritamiseks (Eesti keele tasemeeksamid). Keelefirmade õppeprogrammid on tunnistatud sobivaks Keeleameti poolt (Keeleamet) ning kursustel ópetavad Tartu ja Tallinna ülikooli haridusega eesti keele õpetajad. Eesti keele kursused on sihtrühma hulgas väga populaarsed (INSA 2020: 26). Kursustel õppimine on aga erineva tulemuslikkusega. Palju inimesi on 
korduvalt keelekursustel osalenud, kuid ei suuda siiski tasemeeksamit sooritada ja eesti keeles suhelda (Saar Poll 2013; Eksamistatistika). Kuigi tasuta kursustele pääsevad vaid kiiremad registreerujad, iseloomustab kursusi suur hulk katkestajaid (Vallimäe jt 2018).

Uuringufirmad on keelekursuste kohta viinud läbi küsitlusi nii keeleõppe pakkujate (Vallimäe jt 2018) kui õppijate (Saar Poll 2013) vaatekohast, kuid kursuste õppemetoodikat ei ole süsteemselt uuritud. Õppemetoodikal on keeleõppe tulemustele aga oluline mõju (Gardner 2007; Dörnyei 1994), vajades seega pidevat uurimist ja arendamist. Siinses artiklis analüüsitakse keelefirmade õpetajate seas 2020. aasta lõpus läbi viidud õppeteemalise küsitluse tulemusi ning arutletakse nende ja tänapäevaste teise keele õppe seisukohtade põhjal eesti keele kui teise keele õppe arendamise võimaluste üle.

Keelt võib õppida mitut moodi. Teise keele õppe jaoks on aegade jooksul välja töötatud palju meetodeid, millest populaarsemad on olnud grammatika-tõlkemeetod (ingl grammar-translation method) ja kommunikatiivsed meetodid (ingl communicative methods) (Demirezen 2011). Grammatika-tõlkemeetodit iseloomustab õpikutekstide lugemine-tõlkimine, grammatikateooria õppimine ja kontekstivabade kirjalike grammatikaharjutuste tegemine. Seda meetodit kasutades võivad õppijad hakata lugemistekstidest aru saama, kuid õpitavas keeles nad ise suhelda ei suuda. Kommunikatiivsete meetodite korral kasutatakse autentseid õppematerjale ja aktiivõppemeetodeid ning tegeldakse nelja osaoskuse (kuulamine, lugemine, rääkimine, kirjutamine) arendamisega. (Larsen-Freeman 2007) Viimasel ajal on eesti keele kui teise keele täiskasvanuõppes hakatud rohkem kasutama ka mängustamist (ingl gamification) (nt improteatri elemendid, pantomiimid, liikumine) (vt Kitsnik 2019). Üldiselt ollakse tänapäeval seisukohal, et ideaalset ja igas olukorras toimivat õppemeetodit pole olemas. Samas eksisteerivad siiski üldised keeleõppimist soodustavad põhimõtted, milleks võib pidada haaravust (ingl engagement), aktiivsust (ingl activity) ja jõukohasust (ingl affordability) (Dörnyei 1994; Richards 2006; Brophy 2016; Tomlinson 2010, 2012; Kitsnik 2020). 


\subsection{Keeleõppe haaravus}

Õpitava omandamiseks peab olema sellest kognitiivselt ja emotsionaalselt haaratud (Tomlinson 2010, 2012). Kognitiivselt haaratud saab olla vaid sellest, mis on huvitav ja tähenduslik. Huvitav (ingl interesting) tähendab midagi, mis tõmbab tähelepanu ja äratab soovi millestki teada saada (Sõnaveeb). Tähenduslik (ingl meaningful) tähendab, et vastandina lihtsalt päheõppimisele seostub materjal õppija varasema teadmise või kogemusega (APA). Üldjuhul on huvitavad ja tähenduslikud teemad tänapäevased ja elulised. Inimeste huvid on alati ka mõnevõrra erinevad, seega peaks keelekursustel käsitlema mitmekesiseid teemasid. Emotsionaalne haaratus sõltub teema käsitlusest ja seda soodustab üllatavus, intrigeerivus, kujutlusvõime õhutamine jmt (Brophy 2016; Tomlinson 2010). Oluline on ka õppetegevuste haaravus. Õppetegevusi saab muuta väga haaravaks näiteks mängustamise ja improvisatsiooni abil (Kitsnik 2019; Kitsnik \& Hallas 2020; Kitsnik \& Berezina 2021). Kui õppijad on õpitavast kognitiivselt ja emotsionaalselt haaratud, siis tunnevad nad õppimise väljakutsest rõõmu ega pea õpitavale keskendumiseks tegema suurt pingutust (Nordin \& Eng 2017). Nad panustavad sel juhul õppimisse rohkem energiat ning töötlevad õpitavat materjali intensiivsemalt (Tomlinson 2010), mis toob kaasa õppimise tõhususe tõusu.

\subsection{Keeleõppe aktiivsus}

Keele omandamiseks on vaja keelega aktiivselt tegeleda ning omandatavat materjali mitmekülgselt töödelda. Õppija aju, kuuldes-nähes palju huvipakkuvat loomulikku keelekasutust, hakkab seda aktiivselt töötlema ning sagedasi konstruktsioone tähele panema, konteksti toel mõistma ja meelde jätma (Ellis 2003; Kitsnik 2018). Kõige loomulikumat keelelist sisendit saab inimene keelekeskkonnas viibides. Eesti keele tundides on aga samuti võimalik ja vajalik pakkuda palju mitmekesist autentset või autentselaadset sisendit ning selle töötlemist soodustavaid tekstieelseid, 
-aegseid ja -järgseid ülesandeid (Richards 2006; Kärtner 2000a, 2000b). Aktiivsed ülesanded peavad olema mitmekesised ning tekitama õppijais päris soovi tekstides käsitletud teemade üle mõelda, kasutades seejuures ka kõrgema taseme mõtlemisoskusi (Krull 2018).

Lisaks sisendi aktiivsele töötlemisele peab keeleõppija saama ka palju motiveerivaid võimalusi keelt erisugustes suhtlussituatsioonides ise kasutada. Keeletunnis sobivad selleks kommunikatiivsed aktiivõppe meetodid: improdialoogid, rollimängud, arutelud, ajurünnakud jmt (Karm 2013), mille puhul on oluline, et ülesannete sisu ja vorm õppijaid tegelikult käivitaksid. Tõstmaks iga õppija rääkimismahtu, tuleks suurem osa ülesandeid ja harjutusi täita paarides ja väikestes rühmades (Kärtner 2000c). Grammatikat ja sõnavaragi tuleks õpetada peamiselt aktiivõppe meetodite abil. Õppijad peaksid saama piisavalt võimalusi tegelikku keelekasutust ise analüüsida ja avastada selles peituvaid seaduspärasusi. Raskemini omandatavaid, kuid vastaval tasemel funktsionaalselt olulisi teemasid tuleks harjutada kommunikatiivsete grammatikaharjutustega, milles õppijad kasutavad harjutatavat vormi nii, et harjutusel on ka mingi suhtluseesmärk (Thornbury 2019). Aktiivõppe tõhususe jaoks on väga oluline klassi kõrge energiatase (Dewaele 2015, 2005; Richards 2006), mille saavutamisele aitab kaasa liikumine ja mängustamine (Kitsnik 2019).

\subsection{Keeleõppe jõukohasus}

Tõhusaks õppimiseks peavad õppematerjalid ja õppetegevused olema jõukohased - vastama õppijate olemasolevale keeleoskustasemele ja neid sealt parajal määral edasi viima. Keelekursustel tähendab see eelkõige õppematerjali ja õppetegevuste vastavust "Euroopa keeleõppe raamdokumendi" funktsionaalsetele tasemekirjeldustele (CEFR 2007) ning tasemekohase sõnavara ja grammatika kasutamist (vt nt Sõnaveeb). Peab arvestama, et keeleoskust ei saavutata teatud teemade äraõppimisega, keelega targalt tegeledes arenevad nii keeleline keerukus (ingl complexity), täpsus (ingl accuracy) kui ka sujuvus (ingl fluency) 
(Housen jt 2012) vastavalt eesti keele oskuse loomulikule arengurajale. Õpetaja peab suutma neid protsesse targalt suunata, pakkudes õppijaile nii implitsiitset ehk alateadlikku kui ka eksplitsiitset ehk seletuspõhist ópet. Õpetaja peab mõistma, et keelestruktuuride kasutusoskus areneb vaid keelt kasutades ja vigu tehes, andma õppijaile selleks palju võimalusi ning oskama neid seejuures parajal määral toetada.

Hästi üles ehitatud keeletunnis on õppetegevused omavahel seostatud ning sobivalt järjestatud (kergemalt raskemaks, kindlat lahendust nõudvalt loovamaks), õppijaile esitatakse suhtlusülesannete täitmiseks asjakohased näidised, õpetatakse vajalikku sõnavara ja keelestruktuure. Ülesanded ja õppetegevused peaksid olema eri tüüpi ja arvestama eri õpistiiliga õppijate vajadusi. Heas keeletunnis arendatakse ka osaoskuste alaoskusi ja õpioskusi (nt lugemis- ja kuulamisstrateegiaid, sõnade ja keelestruktuuride õppimise strateegiaid, kirjutamist kui protsessi) (Thornbury 2002; Harmer 2007). Lisaks peab keeleõpe arendama õppijate üldpädevusi (õpioskusi, kriitilist tekstimõistmist, digioskusi, suhtlemisoskust, iseseisva töö oskust, koostööoskust, loovust), üldinimlikke väärtusi ning kultuuritundlikkust (Tomlinson 2013; Kikas \& Toomela 2015).

Õppimise jõukohaseks muutmisel on oluline roll ka tunni õhkkonnal. Ainult siis, kui õhkkond on positiivne ja turvaline, on õppijad võimelised vastu võtma oma arengu jaoks olulisi keelelisi ja kognitiivseid väljakutseid (Dörnyei \& Murphey 2003; Kitsnik 2019; Hadfield 2010).

\section{Uurimismaterjal ja -metoodika}

Uurimismaterjali kogumiseks koostati 35 küsimusega veebiküsitlus. Kutse küsitlusele vastata saadeti Keeleametilt heakskiidu saanud keelefirmadele (Keeleamet), Eesti keele majadele (Eesti keele majad) ja uussisserändajaid õpetavale kohanemisprogrammi õpetajatele (Kohanemisprogramm). Küsitlus oli anonüümne, vastajatelt küsiti õpetamise staaži, tunni õppekeele, õppemetoodika ja õppematerjalide ning õppijate arvatava keeleõppemotivatsiooni kohta. Igal õpetajal paluti 
valida üks keeleoskustase (A1, A2, B1, B2 või C1), vastavalt millele nad küsimustele vastasid.

Küsitlusele vastas 59 tegevõpetajat. A1-taseme kohta andis vastuseid 13, A2-taseme kohta 13, B1-taseme kohta 15, B2-taseme kohta 11 ja C1-taseme kohta 7 õpetajat. Alla aastase eesti keele kui teise keele õpetamise staažiga on vastajatest $8 \%$ (tasemetel A1-B1), 1-5-aastase staažiga $19 \%$ (enamuses tasemetel A1-B1), 6-10-aastase staažiga 12\% (tasemetel A1-B2) ja üle 10-aastase staažiga 61\% (kõigil tasemetel). Ainult eesti keeles viib oma tunde läbi 23\% A2-taseme, 20\% B1-taseme, 36\% B2-taseme ja 72\% C1-taseme õpetajatest. Ülejäänud tunnid toimuvad peamiselt eesti ja vene või eesti ja inglise keeles. Õpetajate arvates õpivad nende õpilased eesti keelt kõige rohkem kolmel põhjusel: soovist sooritada eesti keele tasemeeksam (64\% vastajatest, kõigil tasemetel), leida tööd või saada sisse kooli (63\% vastajatest, kõigil tasemetel) ja saada hakkama igapäevaelus (59\% vastajatest, rohkem tasemetel A1-B1). Neljandaks põhjuseks peetakse õppijate soovi suhelda eestlastega (37\% vastajatest, kõige rohkem B2-tasemel).

Ôpetajad kasutavad enda hinnangul kõige rohkem kommunikatiivseid meetodeid, sh mängustamist, aga ka grammatika-tõlkemeetodit. Õpikutest kasutatakse kõige rohkem: A1-tasemel "E nagu Eesti" (Pesti 2016) ja "Tere" (Mangus \& Simmul 2009, 2020); A2-tasemel "E nagu Eesti”, “Tere jälle” (Mangus \& Simmul 2016), tugevamate gruppidega ka "Naljaga pooleks" (Kitsnik, Kingisepp 2006); B1-tasemel "Naljaga pooleks" ja "Eesti keele õpik B1, B2" (Kitsnik 2008), B2-tasemel " $K$ nagu Kihnu" (Pesti 2018) ning keelefirmade endi koostatud materjale; C1-tasemel ópikuid ei kasutata (neid ka peaaegu ei ole).

Küsitluses oli kuus peamist plokki: lugemis-, kuulamis-, rääkimis-, kirjutamis-, sõnavara- ja grammatikaoskuse arendamine. Igas osas oli esitatud õppetegevuste loetelu, mille hulgast paluti vastajail ära märkida enda kursustel peamiselt kasutatavad, võimalik oli lisada ka oma vastusevariante. Vaba vastusena paluti kirjutada, mis valmistab õppijatele selle osa arendamisel probleeme ning jagada vastava osa arendamisel ka üht head kogemust. 
Andmeid analüüsiti nii kvalitatiivselt kui kvantitatiivselt. Küsitluse vastused on esitatud kuues osas - neli osaoskust, grammatika ja sõnavara. Iga taseme vastajate hulgast leiti peamiselt kasutatavate õppetegevuste osakaal. Tulemused on esitatud tabelina, milles on halli värviga märgitud kõik üle $50 \%$ osakaalud. Vabavastused probleemide ja heade kogemuste kohta jagati sarnaste vastuste markeerimisel saadud kategooriatesse. Kategooriad on esitatud koos vastuste näidetega ning sagedasemate kategooriate juures on ära toodud ka nende osakaalud koguvastustest.

\section{Küsitluse tulemused}

\subsection{Lugemisoskuse arendamine}

Peamised lugemisoskuse arendamiseks kasutatavad tekstitüübid on esitatud tabelis 1. Tabelis 2 on lugemisoskuse arendamiseks peamiselt kasutatavad õppetegevused.

TABEL 1. Lugemisoskuse arendamiseks kasutatavad tekstitü̈̈bid (osakaal vastava taseme ópetajatest, üle 50\% on märgistatud halliga)

\begin{tabular}{|l|r|r|r|r|r|}
\hline Tekstitüüp & A1 & A2 & B1 & B2 & C1 \\
\hline Opikutekstid & 100 & 85 & 93 & 100 & 43 \\
\hline Autentsed tekstid & 62 & 85 & 73 & 100 & 100 \\
\hline Õpetaja enda koostatud tekstid & 69 & 39 & 53 & 55 & 14 \\
\hline
\end{tabular}

TABEL 2. Lugemisoskuse arendamiseks kasutatavad õppetegevused (osakaal vastava taseme ópetajatest, üle 50\% on märgistatud halliga)

\begin{tabular}{|l|c|c|c|c|c|}
\hline Õppetegevus & A1 & A2 & B1 & B2 & C1 \\
\hline Lugemiseelsed ülesanded & 46 & 54 & 80 & 91 & 86 \\
\hline $\begin{array}{l}\text { Lugemisaegsed ülesanded } \\
\text { (eksamitüüpi) }\end{array}$ & 39 & 77 & 73 & 100 & 71 \\
\hline $\begin{array}{l}\text { Lugemisaegsed ülesanded } \\
\text { (muud tüüpi) }\end{array}$ & 62 & 39 & 47 & 91 & 71 \\
\hline
\end{tabular}


MARE KITSNIK, KATRIN MIKK

\begin{tabular}{|l|r|r|r|r|c|}
\hline Õppetegevus & A1 & A2 & B1 & B2 & C1 \\
\hline Teksti korduv lugemine & 70 & 39 & 47 & 55 & 29 \\
\hline $\begin{array}{l}\text { Lugemisteksti sõnavaraga } \\
\text { tegelemine }\end{array}$ & 85 & 100 & 100 & 91 & 86 \\
\hline $\begin{array}{l}\text { Lugemisteksti grammatikaga } \\
\text { tegelemine }\end{array}$ & 69 & 46 & 80 & 82 & 43 \\
\hline Lugemisteksti tõlkimine & 85 & 39 & 60 & 36 & 14 \\
\hline Lugemisstrateegiate õppimine & 8 & 23 & 40 & 46 & 57 \\
\hline Loetu ümberjutustamine & 69 & 54 & 67 & 64 & 57 \\
\hline Loetu põhjal arutlemine & 69 & 85 & 100 & 100 & 100 \\
\hline Loetu põhjal kirjutamine & 46 & 31 & 67 & 82 & 71 \\
\hline
\end{tabular}

* Eksamitüüpi ülesanded on riiklikel eesti keele kui teise keele tasemeeksamitel kasutavate ülesannete tüüpi ülesanded (https://harno.ee/tasemeeksamid).

\subsubsection{Lugemisoskuse arendamise probleeme}

Peaaegu kõigil tasemetel märgitakse probleemina tasemekohaste, loomulike ja huvitavate lugemistekstide puudust (20\% vastajatest) (näide 1).

(1) Päris algajale sobivate tekstide vähesus õpikutes, ja ka mujalt on neid raske leida, seepärast teen palju ise. Õpikutekstid algajale kipuvad olema ebaloomulikud ja väga ebahuvitavad. Ometi on minu kogemuse põhjal ka juba väga lihtsa sõnavaraga võimalik kokku panna sisulisi tekste nt eluolust, kultuurist, geograafiast, tegelikult millest iganes. (A1)

Lugemisoskuse arendamise probleemina tuuakse B- ja C-tasemetel välja õppijate napp sõnavara (15\% vastajatest) (näited 2 ja 3 ).

(2) Nigel sõnavara. (B1)

(3) Sõnavara ebapiisav tundmine. (C1)

Peaaegu kõigil tasemetel (va C1) on õpetajate sõnul probleemiks ka õppijate soov teksti sõna-sõnalt tõlkida, lugedes detailidesse takerdumine ning olulise mitte eristada suutmine (näide 4). 
ÕPPETEGEVUSTE HAARAVUS, AKTIIVSUS JA JÕUKOHASUS ...

(4) Mõned õppijad takerduvad detailidesse, ei keskendu ülesandele. On vaja õpetada lugemisstrateegiaid - võtmesõnade leidmist, teha sama tekstiga silmavat ja detailsemat lugemist. (A2)

Probleemina nimetatakse ka õppijate soovimatust teha passiivseid lugemisülesandeid (näide 5).

(5) Õppijad tulevad kursusele tavaliselt üsna väsinuna ja seega on näha, et nad ei taha lugemisele väga keskenduda ning tahaksid teha midagi aktiivsemat. (A2)

B-tasemel tuuakse välja ka lugemise ebameeldivus kooliaja mälestuste tõttu (näide 6) ning soovimatus teha kodutöid.

(6) Õppijad ei taha tekstiga töötada, kuna see meenutab neile kooliaega, kus valdavaks keeleõppemeetodiks oli ladina kooli meetod - loed, tõlgid, tuubid pähe. Seetõttu keskendun muudele tegevustele tunnis, mille sisse püüan lugemise osa salamisi ära peita, et see ei tunduks õppijale tüütu ja vastik tegevus. (B2)

Veel mainitakse probleemina tekstide keerulisust (erinev tähestik, lauseehitus), hääldusprobleeme, lugemisülesannete nappust, lugemise õpetamise ajamahukust. B-tasemel tuuakse esile õppijate nõrka lugemisoskust ka emakeeles ning oskamatust teksti ümber jutustada ja C-tasemel mainitakse probleemina grammatika nõrka tundmist ning õppijate erinevat taset rühmas.

\subsubsection{Lugemisoskuse arendamise häid kogemusi}

Õpetajate sõnul on lugemisoskust aidanud hästi arendada järgmised õppetegevused: kooris lugemine (mis julgustab eriti algajaid), lugemine koos paarilisega, ilmekas rollides lugemine, teksti osadeks jaotamine (iga õppija loeb ühe osa ja räägib pärast teistele), tekstide ja piltide ühendamine, info otsimine lühikestest tekstidest, teksti sõnavarast arusaamiseks Google'ist piltide otsimine, teksti lugemise järgne "ristküsitlus" (näide 7). 
(7) Teksti kohta tuleb esitada palju küsimusi, et kindlaks teha, kas tekstist saadakse õigesti aru. See on palju efektiivsem kui "loe ja tõlgi", kuna õppija on kogu aeg keelekeskkonnas, ei lülita end ümber oma emakeelele saab kinnistada teatud lausekonstruktsioone ja sõnavara. (B1)

Korduvalt tuuakse välja ka lugemistekstide huvitavuse olulisus (näide 8).

(8) Linnalehes ilmus sel sügisel artikkel Koit Toomest. Vaatasime enne lugemist mitmeid muusikavideoid, otsisime fakte elust ja loomingust, lisasin ise mõned huvitavad seigad. Kui ajalehed avasime, oli äratundmisrõõm ehe ja ülesanded tundusid huvitavad ning tekst oli kohe "lihtsas keeles ja arusaadavalt kirjutatud”. (B1)

Kõrgematel tasemetel mainitakse võimalust lasta õppijail ennast huvitavad tekstid tundi kaasa tuua ja teistele tutvustada ning ka tekstide põhjal aktiivsemate ülesannete tegemist (näide 9).

(9) Näiteks teksti põhjal rollimängud aktiveerivad teksti paremini mõistma. (B2)

Korduvalt mainitakse huvitavana ka teksti grammatikaga tegelemist (näide 10).

(10) Kui lugemise käigus selgitada eesti keele lauseehituse ja grammatika omapära. (A2)

Õpetajad peavad kasulikuks ka õppijais igapäevase eestikeelsete tekstide lugemise harjumuse tekitamiseks neile ajalehtede ja ajakirjade koju kaasa andmist või kinkimist.

Kokkuvõttes tundub lugemisoskuse arendamine osaliselt aktiivne. Kasutatakse palju õpikutekste ja autentseid tekste ning traditsioonilisi lugemisoskust arendavaid tegevusi: tehakse nii eksamitüüpi kui ka muud tüüpi lugemisülesandeid, tegeldakse tekstide sõnavaraga, arutletakse loetu põhjal, jutustatakse tekste ümber ja tegeldakse tekstide grammatikaga. Kasutatakse ka aktiivõppemeetodeid. Lugemisoskuse arendamine tundub keskmiselt haarav. Õpetajad toovad esile õpikutekstide kohatise ebaloomulikkuse ja ebahuvitavuse, mille tõttu peavad nad tekstide huvitavamaks muutmiseks ise lisamaterjali otsima. Õpetajad 
peavad õppijaile haaravaks loovate aktiivõppemeetodite kasutamist ning lugemistekstide grammatikaga tegelemist. Lugemisoskuse arendamine on keskmiselt jõukohane. Osa õpetajaid toob välja jõukohasusega seotud probleeme. Esimene probleem on õppijate napp sõnavara, mis takistab lugemistekstide mõistmist. Teise probleemina nähakse õppijate üldist nõrka lugemisoskust: õppijad kalduvad teksti sõna-sõnalt lugema ja detailidesse takerduma. Lugemist raskendab õpetajate arvates ka osa tekstide keerukas lauseehitus ning õppijate erinev tase rühmas. Lugemisstrateegiaid õpetab kõrgematel tasemetel peaaegu pool õpetajatest, madalamatel tasemetel aga vaid väike osa õpetajatest.

\subsection{Kuulamisoskuse arendamine}

Kuulamisoskuse arendamiseks peamiselt kasutatavad tekstid on toodud tabelis 3. Tabelis 4 on esitatud peamiselt kasutatavad õppetegevused.

TABEL 3. Kunlamisoskuse arendamiseks kasutatavad tekstitüübid (osakaal vastava taseme õpetajatest, üle 50\% on märgistatud halliga)

\begin{tabular}{|l|r|r|r|r|c|}
\hline Tekstitüüp & A1 & A2 & B1 & B2 & C1 \\
\hline Õpikutekstid & 85 & 62 & 80 & 82 & 43 \\
\hline Autentsed tekstid & 54 & 62 & 80 & 100 & 71 \\
\hline Oppetaja enda jutt & 92 & 80 & 80 & 64 & 86 \\
\hline Tunnikülalise jutt & 8 & 0 & 28 & 36 & 43 \\
\hline
\end{tabular}

TABEL 4. Kuulamisoskuse arendamiseks kasutatavad öppetegevused (osakaal vastava taseme ópetajatest, üle $50 \%$ on märgistatud halliga)

\begin{tabular}{|l|c|c|c|c|c|}
\hline Õppetegevus & A1 & A2 & B1 & B2 & C1 \\
\hline Kuulamiseelsed ülesanded & 62 & 54 & 87 & 91 & 71 \\
\hline $\begin{array}{l}\text { Kuulamisaegsed ülesanded } \\
\text { (eksamitüüpi) }\end{array}$ & 39 & 77 & 80 & 100 & 71 \\
\hline $\begin{array}{l}\text { Kuulamisaegsed ülesanded } \\
\text { (muud tüüpi) }\end{array}$ & 39 & 62 & 60 & 82 & 57 \\
\hline Teksti korduv kuulamine & 85 & 92 & 93 & 82 & 71 \\
\hline
\end{tabular}


MARE KITSNIK, KATRIN MIKK

\begin{tabular}{|l|r|r|r|r|c|}
\hline Õppetegevus & A1 & A2 & B1 & B2 & C1 \\
\hline Kuulamisteksti lugemine & 80 & 54 & 53 & 46 & 29 \\
\hline $\begin{array}{l}\text { Kuulamisteksti sõnavaraga } \\
\text { tegelemine }\end{array}$ & 92 & 85 & 80 & 82 & 100 \\
\hline $\begin{array}{l}\text { Kuulamisteksti grammatikaga } \\
\text { tegelemine }\end{array}$ & 39 & 39 & 67 & 55 & 43 \\
\hline Kuulamisteksti tõlkimine & 62 & 15 & 40 & 27 & 0 \\
\hline Kuulamisstrateegiate õppimine & 0 & 23 & 47 & 64 & 57 \\
\hline Kuuldu põhjal arutlemine & 80 & 85 & 100 & 100 & 71 \\
\hline Kuuldu põhjal kirjutamine & 31 & 23 & 73 & 64 & 43 \\
\hline
\end{tabular}

Eksamitüüpi ülesanded on riiklikel eesti keele kui teise keele tasemeeksamitel kasutavate ülesannete tüüpi ülesanded (https://harno.ee/tasemeeksamid).

\subsubsection{Kuulamisoskuse arendamise probleeme}

Kuulamisoskuse arendamisel toob $42 \%$ vastajatest välja loomulike, jõukohaste ja kvaliteetsete tekstide leidmise raskuse. Probleem esineb kõigil tasemetel, kuid A1-B1 tasemel oli seda mainitud rohkem (näited 11-13).

(11) Heade kuulamismaterjalide vähesus. Olemasolevate kuulamismaterjalide "kunstlik" keelekasutus ja esitus. (A1)

(12) Tasemele vastavate kuulamistekstide kogumikke, kus oleks esindatud erinevad teemad, ei ole. Originaalteksti kasutamise teeb raskeks esineja halb diktsioon, kõne kiirus, tasemele mittevastav sõnavara. (B1)

(13) Heade tekstide leidmine, milles oleks mingi teema esitatud konkreetselt, heas sõnastuses ja hea helikvaliteediga. (C1)

Õppijaile mõjub halvasti ka ebasobivate ülesannete kasutamine (näide 14).

(14) Jõukohaste ülesannete valimine. Kuulamisülesanded tekitavad tihtipeale ärevust. Kui õppija tunneb, et kuulamistekst on liiga raske, tekib trots ja väike kriis. (A1)

Teiseks suuremaks probleemiks on õppijate madal kuulamisoskus, mille tõi esile 32\% vastanutest. Probleem esineb kõigil tasemetel (näited 15-17). 
(15) Õppijad soovivad alati kõigest aru saada, kuid erinevad ülesanded nõuavad erineval tasemel arusaamist. (A2)

(16) Õppijate vähene keskendumisoskus, ülemäärane hädaldamine ja halva tulemuse prognoosimine. (B1)

(17) Kärsitus, õppijad on üsna kärsitud, et süveneda, sest B2-grupis inimene saab ju üldjoontes kuuldust aru ning ta arvab, et sellest piisab teksti mõistmiseks. (B2)

Samuti näevad õpetajad probleemina õppijate vähest eestikeelsete tekstide kuulamist väljaspool keeletunde. Õppijad ei kuula ise tekste ja ka õpetajal on raske neile keelekeskkonnast kuulamisvõimalusi leida.

\subsubsection{Kuulamisoskuse arendamise häid kogemusi}

Häid kogemusi kuulamisoskuse arendamisel on õpetajail päris palju. Esiteks soovitatakse alguses raskena tunduvat teksti korduvalt kuulata (näide 18). Teksti kuulamise ajal võib seda ka paberilt jälgida, näiteks filmi juurde subtiitreid lugeda.

(18) Positiivne kogemus on olnud näiteks sellega, kui oleme võtnud kuulamisülesandeks mõne algul liiga raske ja kiirena näiva teksti, siis seda korduvalt ja korduvalt üle kuulanud, igal kuulamiskorral järjest uutesse detailidesse süvenedes, kuni lõpuks ongi kõik kuuldu arusaadav - ilma, et õpetaja oleks ühtegi sõna tõlkima pidanud. (A1)

Eri kuulamiskordade ajal võiks täita ka eri tüüpi ülesandeid: näiteks kord üldiselt aru saada, kord detailselt kuulata. Soovitatakse teha ka kuulamiseelseid ja -järgseid ülesandeid (näide 19).

(19) Kuulamisoskuse arendamisel annab häid tulemusi, kui kasutad mitut tegevust korraga: annad kuulamiseelseid ülesandeid, pärast kuulamist tegeled nii sõnavara kui grammatikaga, arutled, siis kuuled veel kord ja annad mingi arutlusel esile kerkinud probleemi põhjal koduse kirjutamisülesande. (C1)

Kuulamisoskuse edukaks arendamiseks on tähtis ka tekstide huvitavus ja informatiivsus. Hea mõjuga on peaaegu alati laulude kuulamine, eriti 
koos videoga. Kuulamisoskuse nagu iga muu oskuse arendamise juures on oluline süstemaatilisus - kuulata tuleks igas tunnis ja ka väljaspool tunde (näiteks panna vabal ajal mängima eesti raadio). Veel arendab kuulamisoskust hästi see, kui õpetaja kasutab tunnis ainult eesti keelt või kui tunnis kasutatakse improelementidega räkimisülesandeid (näide 20) või vestlust videosillas.

(20) Improvisatsioonilised dialoogid, kus ollakse sunnitud kohe vastama. Kui selgitan asju eesti keeles korduvalt ja erinevalt ja kasutan ka kehakeelt, kuni tekib see "ahaa-elamus" ja arusaamine. (A1)

Kokkuvõttes kuulamisoskuse arendamise haaravust ei saa hinnata, sest see teema ei kerki õpetajate vastustes esile, kuigi kuulamistekstide huvitavust ja informatiivsust peetakse oluliseks. Kuulamisoskuse arendamine on osaliselt aktiivne. Kuulamismaterjalina kasutatakse palju autentseid tekste, õpikutekste ja õpetaja enda juttu, kuid tunduvalt vähem tunnikülaliste juttu. Peamiselt tehakse traditsioonilisi kuulamisülesandeid: kuulatakse teksti korduvalt, tegeldakse teksti sõnavaraga, arutatakse kuuldu põhjal ning tehakse nii eksamitüüpi kui ka muud tüüpi kuulamisülesandeid. Mõni õpetaja mainib ka aktiivsete improelementidega rääkimisülesannete positiivset mõju kuulamisoskuse arendamisele. Kuulamisoskuse arendamine ei ole õppijatele alati jõukohane. Kaks viiendikku õpetajatest kurdab loomulike, jõukohaste ja kvaliteetsete kuulamistekstide vähesuse ning kuulamisülesannete ebasobivuse ja õppijates ärevuse tekkimise üle. Kõigil tasemetel peetakse probleemiks ka õppijate vähest kuulamisoskust. Korduva kuulamise ja erisuguste süsteemsete ja kohati ka aktiivsete ülesannete abil on õpetajatel küllaltki palju edukaid kogemusi kuulamistekstide jõukohaseks muutmisega. Kuulamisstrateegiaid õpetatakse aga üldiselt vaid kõrgematel tasemetel.

\subsection{Sõnavaraoskuse arendamine}

Peamised sõnavaraoskuse arendamiseks kasutatavad tegevused on esitatud tabelis 5 . 
ÕPPETEGEVUSTE HAARAVUS, AKTIIVSUS JA JÕUKOHASUS ...

TABEL 5. Sõnavaraoskuse arendamiseks kasutatavad õppetegevused (osakaal vastava taseme öpetajatest, üle 50\% on märgistatud halliga)

\begin{tabular}{|l|c|c|c|c|c|}
\hline Õppetegevus & A1 & A2 & B1 & B2 & C1 \\
\hline Sõnade päheõppimine & 54 & 23 & 47 & 27 & 0 \\
\hline $\begin{array}{l}\text { Fraaside ja tervikväljendite } \\
\text { õppimine }\end{array}$ & 92 & 85 & 100 & 82 & 57 \\
\hline Digilahendused & 46 & 46 & 67 & 46 & 14 \\
\hline Sõnade kordamine & 92 & 77 & 67 & 46 & 14 \\
\hline Sõnade tõlkimine & 85 & 62 & 67 & 82 & 57 \\
\hline Mängustatud tegevused & 54 & 85 & 80 & 73 & 100 \\
\hline Tekstide loomine & 31 & 46 & 73 & 73 & 57 \\
\hline Vestlussituatsioonid & 69 & 77 & 73 & 91 & 100 \\
\hline $\begin{array}{l}\text { Sõnavara postritel, stendidel jms } \\
\text { ümbritsevas keskkonnas }\end{array}$ & 31 & 31 & 27 & 27 & 27 \\
\hline
\end{tabular}

\subsubsection{Sõnavaraoskuse arendamise probleeme}

Sõnavaraoskuse arendamisel peavad õpetajad kõigil tasemetel suureks probleemiks sõnade kehva meeldejäämist õppijatele (46\% vastajatest). Selle põhjusena tuuakse välja õppijate kehv mälu, aga ka tahte, oskuse ja aja puudumist väljaspool tunde iseseisvalt sõnu õppida (näited 21 ja 22).

(21) Suurim probleem on see, et õppijad ei viitsi tihtipeale ise õppesse panustada ja selleks, et õppega edasi liikuda, peame teinekord liiga pikalt tegelema tunnis sõnavara õppimisega. (A1)

(22) Kõige suurema töö peab õppija ise tegema. Sõnade ja väljenditeta pole keelt. Probleemiks on laiskus, eakus, töö jne. (B2)

Suur osa õppijaist ei kasuta õpitud sõnu väljaspool keeletundi ega seosta neid kontekstiga - see takistab sõnade omandamist. Kõrgematel tasemetel on mõnikord probleemiks ka see, et õppijad kasutavad juba tuttavat sõnavara ega ole motiveeritud sünonüümseid väljendusi omandama. Mõnikord on vaja omandada liiga palju uusi sõnu ja väljendeid korraga ja seda ei suudeta teha (näide 23). 
(23) Kui uusi sõnu ja väljendeid on liiga palju, ei suudeta neid meelde jätta ja kasutada. (C1)

Lisaks näevad õpetajad probleeme sõnade keerulisusega. Õppijaile on rasked eesti sõnade kolm põhivormi, sarnase kõlaga sõnad, ühendverbid, sõnade mitmetähenduslikkus ning kõne- ja kirjakeele erinevus. Kõrgematel tasemetel (B2, C1) tuuakse probleemina esile ka uhiuued sõnad, vanasõnade, kõnekäändude ja idioomide tähenduse mõistmine ja nende sobiv kasutamine tekstiloomes ning sõnavälted.

Mõned õpetajad mainivad probleemina ka seda, et õpikutes ei ole sõnavaraõpetus alati süstemaatiliselt läbi mõeldud ega loovalt lahendatud. See nõuab õpetajalt palju lisatööd, mida ei jõua aga alati teha. Uusi sõnu on vaja kohata korduvalt ja eri kontekstis - siis tekivad õppijail sõnaga seosed ja sõna liigub tema püsimällu (näide 24).

(24) Huvitav on see, et mõnikord võib õppija alles kolmandas tunnis huvi tundma hakata sõna tähenduse üle, kuigi eelnevatel tundidel on see mitmes variandis kasutusel olnud (kuna iga tunni lõpus lasen igal õppijal öelda/kirjutada 1-3 sõna, mis ta tahab tunnist kaasa võtta ja elus kasutama hakata, ja see on ka tunni lõpus kõlanud). (B1)

\subsubsection{Sõnavaraoskuse arendamise häid kogemusi}

Õpetajad nimetavad üsna palju võtteid, mida nad on sõnavara õpetamisel edukalt kasutanud. Esiteks püütakse panna õppijaid sõnu kordama: õppijatel on väike märkmik, kuhu nad uued vajalikud sõnad kirja panevad ja neid siis sobival hetkel kordavad (näide 25); ópitakse pähe sõnu, väljendeid ja dialooge; kirjutatakse sõnu läbi jmt. Kasutatakse aga ka loovamaid meetodeid: lõpetatakse sõnaalgusi, koostatakse uute sõnadega kettmeetodil jutte jm (näide 26). Veel kasutatakse palju sõnakaarte (nii paberil kui ka elektrooniliselt) ja pilte.

(25) Kordamine on tarkuse ema. Küsin näiteks tunni lõpus õppijatelt, mis sõna või väljendi tänasest tunnist meelde jätsite. Kui keegi mõnda ammuõpitud sõna ei tea, siis küsin järgmisel tunnil just temalt midagi sellist, kus ta peab seda sõna või väljendit kasutama. (B1) 
ÕPPETEGEVUSTE HAARAVUS, AKTIIVSUS JA JÕUKOHASUS ...

(26) Õpitud vanasõnu jm huvitavaid väljendeid kasutatakse vestlustes, ettekannetes jm. (C1)

Veel kasutavad õpetajad palju sõnade analüüsimise meetodeid: seletatakse sõnade tähendusi, leitakse sünonüüme, antonüüme ja naabersõnasid, kategoriseeritakse sõnu eri alustel, moodustatakse sõnapesasid ja sõnaahelaid, võrreldakse sarnaseid sõnu ja leitakse koomilisi momente nende segiminekust (abikaasa - abikassa). Nende tegevuste juures kasutatakse ka Eesti Keele Instituudi digitaalseid vahendeid (EKI vahendid).

Mitu õpetajat rõhutab ka vajadust õppida sõnu fraasidena (näide 27).

(27) eraldi uusi sõnu ma tavaliselt ei õpetaja, see käib läbi fraasi või väljendi. (A1)

Küllalt levinud on ka erisugused mängustatud tegevused sõnavara õpetamiseks: sõnaseletusmäng Alias, lauamängud, ristsõnad, sõnasedelite asjadele kleepimine (näide 28).

(28) Laua- ja kaardimängude kasutamine arendab spontaansust ja loovust. Mängustatud tegevused meeldivad kõigile gruppidele, nt kordamismäng "Mulle meeldib põrandaid pesta, kus korratakse kõigi eelnevalt öeldud väljendeid". See tekitab alati positiivset üllatust, kui hea on keskmise õppija mälu. (B1)

Kokkuvõttes on sõnavaraõpe üsna aktiivne ja tundub keskmiselt haarav. Sõnavara õppimiseks kasutatakse mitmesuguseid tegevusi: sõnu õpitakse fraasides ja tervikväljendites, sõnu tõlgitakse, korratakse ja analüüsitakse, neid kasutatakse vestlussituatsioonides ja muus tekstiloomes, kasutatakse digivahendeid ja mängustatud meetodeid. Samal ajal ei ole sõnavaraõpe paljudele õppijatele kõigil tasemetel jõukohane. Peaaegu poolte õpetajate arvates ei jää õppijatele uued sõnad meelde, mille põhjuseks peetakse õppijate kehva mälu, soovimatust iseseisvalt töötada ja sõnade mitteseostamist kontekstiga. Veel jääb kõlama õpetajate arvamus eestikeelsete sõnade erilise keerulisuse kohta (näiteks vajadus õppida iga sõna kindlasti kolmes põhivormis). 


\subsection{Grammatikaoskuse arendamine}

Peamised grammatikaoskuse arendamiseks kasutatavad õppetegevused on esitatud tabelis 6 .

TABEL 6. Grammatikaoskuse arendamiseks kasutatavad óppetegevused (osakaal vastava taseme õpetajatest, üle 50\% on märgistatud halliga)

\begin{tabular}{|l|c|c|c|c|c|}
\hline Õppetegevus & A1 & A2 & B1 & B2 & C1 \\
\hline $\begin{array}{l}\text { Öpikus/töövihikus olevad } \\
\text { ulesanded }\end{array}$ & 100 & 77 & 93 & 91 & 57 \\
\hline $\begin{array}{l}\text { Grammatikatabelite } \\
\text { uurimine }\end{array}$ & 23 & 39 & 40 & 73 & 29 \\
\hline $\begin{array}{l}\text { Grammatikareeglite } \\
\text { seletamine }\end{array}$ & 100 & 69 & 87 & 91 & 100 \\
\hline Õpetaja loodud ülesanded & 54 & 46 & 67 & 73 & 43 \\
\hline Opppijate endi avastused & 54 & 62 & 67 & 82 & 43 \\
\hline Mängustatud ülesanded & 54 & 85 & 73 & 82 & 57 \\
\hline Tekstiloome & 46 & 23 & 67 & 82 & 57 \\
\hline Lünkharjutused & 92 & 80 & 87 & 91 & 57 \\
\hline Jutustamine & 31 & 15 & 60 & 64 & 29 \\
\hline Kirjeldamine & 54 & 39 & 67 & 91 & 29 \\
\hline Võrdlemine & 46 & 69 & 67 & 82 & 29 \\
\hline Skeemide kasutamine & 54 & 23 & 60 & 82 & 43 \\
\hline Piltide kasutamine & 62 & 69 & 73 & 64 & 14 \\
\hline Audio- ja videoülesanded & 54 & 46 & 60 & 64 & 43 \\
\hline
\end{tabular}

\subsubsection{Grammatikaoskuse arendamise probleeme}

Grammatikaoskuse arendamisel nähakse sagedasema probleemina õppijate emakeele ja eesti keele grammatika erinevusi (22\% vastajatest, kõigil tasemetel). Konkreetsete raskete teemadena tuuakse välja käänete süsteemi, infinitiive, lause sõnajärge, liht- ja täisminevikku, sihitise käändeid ja muid rektsioonierinevusi. 
Sageduselt järgmine probleem on see, et õpitud grammatika ei jõua õppijate tegelikku keelekasutusse (15\% vastajatest, näited 29 ja 30).

(29) Õppijad saavad aru, aga rääkimisel ja kirjutamisel teevad ühtesid ja samu vigu. (B1)

(30) Õppijad, kes ei õpi ära või ei saa aru grammatika olulisusest ja jätkavad valesti rääkimist. (B2)

Probleemina tuuakse välja ka otsustamine, kui palju grammatikat õpetada. Seda raskendab asjaolu, et alati viibivad rühmas koos eri tüüpi õppijad: need, kes soovivad ja vajavad grammatikaseletusi, ja need, kes mitte (näide 31).

(31) Õppijad jagunevad laias laastus kaheks: ühed, kes väga tahavad (ja ka minu meelest tõesti vajavad) eksplitsiitseid grammatikaseletusi, et keeles selgust saada ja ennast kindlalt tunda, ja teised, kes vahetut grammatikat ei talu ja kelle igasugune grammatikatabel ajab lootusetult segadusse. Enamasti on õppija puhul muidugi tegemist mingi nende kahe kalduvuse kombinatsiooniga, aga kipub ikka olema nii, et kui ühele suunale üritad vastu tulla, siis teine pool kohe kannatab. (A1)

Palju õppijaid on koolist ja muudest varasematest keeleõppekogemustest omandanud hoiaku grammatika suuremahulise õppimise vajalikkuse suhtes ning ka see võib hakata keeleõpet segama (näited 32 ja 33).

(32) Täiskasvanud tahavad liiga palju sellega tegeleda, tahavad loogikat ja selgeid vastuseid, uurivad iga üksikjuhu kohta, et miks ja kuidas. See võtab liiga palju aega. (A1)

(33) Kui õppijad hakkavad iga sõna kohta eraldi küsima, aga miks, aga miks, aga miks jne. See on jube tüütu. (B2)

Mõnikord tunnevad õppijad eesti keele grammatika keerulisuse ees ka liiga suurt hirmu. (näide 34).

(34) Kui pidevalt hakkab korduma lause "eesti keel on raske", siis on natuke rohkem vaja pingutada - rääkida rohkem keelest ja vähem grammatikast. Rõhuda sellele, kui palju õppijad tegelikult juba oskavad, kiita ja tunnustada (A1). 
Õpetajate jaoks on probleemiks ka see, et paljud õppijad ei tunne grammatikatermineid ega oma emakeele grammatikat, mis raskendab grammatika seletamist (näide 35).

(35) Inimestel puuduvad vajalikud teadmised ka emakeeles, et grammatikat õppida. Inimesed ei tea, kuidas keel töötab. Heal juhul teavad nad ainsust ja mitmust ning olevikku ja minevikku. (A1)

Probleemina mainitakse veel ajapuudust grammatika piisavaks kordamiseks; teadmatust, mis keeles grammatikat õpetada, et kõik sellest aru saaksid, ning puudusi õppematerjalides (näide 36).

(36) Õpikutes tormatakse mõnikord ette loomulikust omandamise järjekorrast, nt sihitise käänded tulevad ühe suure teemana, ehkki sellele on parem läheneda jupikaupa. (A2)

\subsubsection{Grammatikaoskuse arendamise häid kogemusi}

Häid tulemusi grammatika õpetamisel annavad paljude õpetajate arvates näidiste esitamine, grammatikatabelitega tutvumine, pidev harjutamine ja kordamine (nt lünkharjutuste täitmine) (näide 37).

(37) Kui kursuse alguses tutvuda grammatikatabelitega ja alustada näiteks käänetevaheliste seostega, siis seaduspärasused avaldavad muljet. Liiga palju on levinud väärarvamusi, mida laisad õppijadki levitavad, et eesti keeles pole loogikat ega reegleid. On küll! Pisikesed toimivad reeglid innustavad. (B2)

Kasulik on juhtida tähelepanu lihtsatele seostele (näide 38), lasta õppijail endil grammatilisi seaduspärasusi avastada (näide 39), ise reeglid sõnastada, ise teemasid teistele (nt puudunutele) õpetada ja teiste vigu parandada. Sobivaks peetakse ka veebipõhiste vahendite (nt Sõnaveebi) kasutamist.

(38) Lühikesed meeldejäävad reeglid, nt - ne $\rightarrow$-se, värvide õpetamisel efektiivne. Aga näited aitavad peamiselt, näited nagu luuletus pähe ja nende baasil seosed uutes olukordades. (A1) 
ÕPPETEGEVUSTE HAARAVUS, AKTIIVSUS JA JÕUKOHASUS ...

(39) Isekoostatud lihtsate tekstide võrdlemine, kus kasutatakse võrdlevalt osastavat ja omastavat, samuti liht- ja täisminevikku. (C1)

Oluliseks peetakse ka grammatikale kohe kasutusväljundi andmist ning seejuures eksida lubamist (näide 40).

(40) Pöördelõppude harjutamine dialoogis on vist kõige tavalisem algtasemel. Lihtsamad asesõnad, ega ma eriti vigu ei paranda, proovime argusest üle saada, et oleks pingevaba ja tore õhkkond õppimiseks ning eksimine on täiesti inimlik. (A1)

Mõned õpetajad peavad oluliseks ka grammatikaseoste visualiseerimist, grammatika õpetamist sobivas kontekstis, huvitavate tekstide abil ja iga osaoskuse juures. Samuti tuleb esile mängustatud meetodite kasu grammatika õpetamisel (loovharjutused, lauamängud) (näited 41 ja 42).

(41) Mängustatud ülesanded, etteantud grammatiliste mudelite rollimängus kasutamine. (B1)

(42) Teha lauseid nii- ja naapidi. Nt kui õpime kasutama des-vormi, siis hiljem püüame teha des-vormi tagurpidi tagasi, nii nagu algselt oli. (B2)

Kokkuvõttes võib grammatikaõpet pidada keskmiselt aktiivseks ja keskmiselt haaravaks. Grammatikat õpitakse kõige sagedamini reeglite seletamise ning õpiku ja töövihiku traditsiooniliste lünkharjutuste abil. Õpetajate sõnul tehakse grammatikat õppides aga küllalt sageli ka mängustatud ülesandeid, kasutatakse pilte ja huvitavaid tekste ning lastakse õppijail endil grammatika kohta avastusi teha ja keelega katsetada. Grammatika õppimine tundub olevat keskmiselt jõukohane, kuid esineb ka mitmeid probleeme. Peamised probleemid on õpetajate arvates õppijate emakeele ja eesti keele grammatika erinevus ning õpitud grammatika mittejõudmine õppijate keelekasutusse, põhjustades korduvaid vigu õppijate tekstides. Probleemina nähakse ka grammatika õpetamise mahtu: eri õppijad vajavad grammatikaõpet eri määral ning osa õppijaid ootab liiga põhjalikku grammatikaõpet. Paljud õppijad ei tunne õpetajate arvates ka grammatikatermineid ning osa opppijaid tunneb grammatika ees hirmu. Õpetajad väidavad ka, et grammatika õpetamine õppematerjalides ei ole sageli loogiline ja õpikutes napib häid harjutusi. 


\subsection{Rääkimisoskuse arendamine}

Rääkimisoskuse arendamiseks peamiselt kasutatavad tegevused on toodud tabelis 7 .

TABEL 7. Rääkimisoskuse arendamiseks kasutatavad õppetegevused (osakaal vastava taseme õpetajatest, üle 50\% on märgistatud halliga)

\begin{tabular}{|l|c|c|c|c|c|}
\hline Õppetegevus & A1 & A2 & B1 & B2 & C1 \\
\hline Õpikus olevad ülesanded & 85 & 62 & 73 & 82 & 43 \\
\hline $\begin{array}{l}\text { Vaba vestlus/arutlus } \\
\text { (õpetaja ja kogu ôpperühm) }\end{array}$ & 92 & 100 & 100 & 100 & 100 \\
\hline $\begin{array}{l}\text { Vaba vestlus/arutlus } \\
\text { (väikestes rühmades) }\end{array}$ & 80 & 80 & 80 & 100 & 86 \\
\hline Vaba vestlus/arutlus (paarides) & 92 & 92 & 87 & 100 & 100 \\
\hline $\begin{array}{l}\text { Vaba vestlus/arutlus } \\
\text { (liikudes ja paarilisi vahetades) }\end{array}$ & 54 & 62 & 60 & 91 & 71 \\
\hline Mudeldialoogid & 80 & 69 & 67 & 46 & 0 \\
\hline Rollimängud & 62 & 92 & 93 & 100 & 57 \\
\hline Improvestlused & 31 & 23 & 60 & 91 & 43 \\
\hline Väitlus & 0 & 15 & 53 & 100 & 57 \\
\hline
\end{tabular}

\subsubsection{Rääkimisoskuse arendamise probleeme}

Kõige sagedasema probleemina (46\% vastajatest kõigil tasemeil) kerkib esile õppijate rääkimishirm ja kartus teha vigu. Ôppijad tunnevad end sageli ebakindlalt, ootavad ópetajalt pidevat tagasisidet, kardavad tunduda naeruväärsed. Mõni õpetaja kirjeldab ka täpsemalt oma tegevust õppijate rääkima julgustamisel (näide 43).

(43) Õpetajana tahan algtasemel julgustada õppijaid lihtsalt igal viisil keelt kasutama ja mitte kartma eksimist, seepärast ma ei paranda kaugeltki kõiki vigu, pigem mõnda üksikut, kui üldse. Õppijates aga tekitab see 
ÕPPETEGEVUSTE HAARAVUS, AKTIIVSUS JA JÕUKOHASUS ...

ebakindlust, ja tihti sellisel juhul teeb paranduse hoopis mõni teine õppija - mis omakorda tekitab õppijates segadust, miks siis õpetaja ei paranda neid. Mõnd õppijat on raske veenda, et võib rääkida ka ilma igas sõnas ja vormis lõpuni kindel olemata. (A1)

Teine suurem probleem rääkimisoskuse arendamisel on õpetajate hinnangul õppijate vähene sõnavara- ja grammatikaoskus. Seda probleemi nimetab kokku $27 \%$ vastajatest ja see esineb samuti kõigil tasemetel. Konkreetsemalt nimetatakse raskusi eesti keele sõnajärje ja rektsiooniga (A1), suutmatust grammatikat kõnes kasutada (A2), lausete arusaamatut moodustamist ja õpitu rakendamist kõnelemisel (B1), piirdumist primitiivse sõnavaraga ja liiga lihtsa, tasemele mittevastava grammatikaga (B2), mugavustsooni jäämist ja mitte edasiarenemist ning kinnistunud valede sõnavormide ja keelendite kasutamist (C1).

Probleemina näevad õpetajad veel raskusi õppijate üldoskuste ja omaduste tõttu. Kui õppijad on introvertsed, neil napib õpetaja hinnangul suhtlemisoskust ja silmaringi, huumorimeelt ja fantaasiat ka emakeeles, on neid raske käivitada ja rääkima saada. Samuti mainitakse mõned korrad üleminekut emakeelele ja vähest enesejuhtivuse oskust (näide 44).

(44) Õppijad ootavad õpetaja tagasisidet ja kui õpetaja jääb mõne teise laua juurde natukene kauemaks pidama, võib eelmises lauas mokalaadaks minna. Mõnikord see võib-olla ei häiri, kuid väga tihti ma seda lubada ei saa, sest inimene on ju üsna mugav ja ei rakenda vestluses uusi õpitud sõnu, kui teda keegi ekstra ei jälgi. Väga vähesed on väga ennastjuhtivad. (B2)

Veel tuuakse mõned korrad välja rääkimisvõimaluste nappust, nii tundide lühiduse kui ka eestlastest tuttavate puudumise tõttu. Mõned õpetajad mainivad, et rääkimisoskuse arendamisega pole erilisi probleeme, sest inimesed üldiselt ikkagi tahavad rääkida. 


\subsubsection{Rääkimisoskuse arendamise häid kogemusi}

Rääkimisoskuse arendamiseks soovitavad õpetajad esiteks lihtsalt palju vabalt rääkida: teha tunnialustusringe, kus kõik räägivad, kuidas neil läheb; esitada küsimusi ja neile vastata; vestelda õpetajaga; rääkida aktuaalsetest uudistest. Madalamatel tasemetel (A1-B1) kasutatakse rääkimisoskuse arendamiseks palju dialooge: neid õpitakse pähe, luuakse ja esitatakse mudeldialooge ja vahetatakse seejuures partnereid (näide 45).

(45) Mudeli abil harjutamine, nii et kõnelemine on toetatud ja ülesandes on muutujaid (nt küsitakse mitmelt kaasõppijalt, mis neile maitseb ja mis ei maitse). Samuti vestluskaaslaste vahetamisega rääkimine (nt "kohtumised"). (A2)

Kasutatakse ka loetud tekstide ümberjutustamist (A1, A2), vestluskaartide ja pildiseeriate järgi jutustamist, lugemistekstide kokkuvõtte tegemist (B1), multifilmidele teksti peale rääkimist. Rõõmustavalt palju mainivad õpetajad kõigil tasemeil peale $\mathrm{C} 1$ mängustatud ülesannete kasulikkust rääkimisoskuse arenemisele. Peamiselt kasutatakse lauamänge, Aliase sõnaseletusmängu ja muid sõnavaramänge. Õpetajad kasutavad endi sõnul palju ka rollimänge, sh improvisatsioonilisi, mille puhul ei ole täpselt ette teada, mida öelda tuleb, seda juba alates tasemest A2 (näide 46) kuni C1.

(46) Konkreetne näide: kohtud oma klassikaaslasega juhuslikult 10 aastat pärast lõpetamist. Vestelge. Analoogilised improvestlused panevad ka kõige tuimema õppija aktiivselt lobisema ja vigadele ei pööra keegi tähelepanu. (B1)

Osa õpetajaid pöörab tähelepanu ka õppijate psühholoogilisele toetamisele: ei katkesta rääkijat, loob klassis toetava õhkkonna, laseb õppijail esineda mitmekesi, kuulab rääkijat aktiivselt ja peegeldab õppija öeldut (näide 47) ning üritab muuta õppimise lõbusamaks (näide 48).

(47) Õppija süvakuulamine, heade mõtete peegeldamine, kõnevoorust kokkuvõtete tegemine. Kui õppijat huviga kuulata, tunneb ta end arukana. (C1) 
ÕPPETEGEVUSTE HAARAVUS, AKTIIVSUS JA JÕUKOHASUS ...

(48) Väga palju aitab ka see, kui ülesandes on mingi väike vimka või huumorikild, naljaga on lõbusam ülesandeid sooritada. (A1)

Kõrgematel tasemetel on osutunud kasulikuks suunata õppijaid oma tekstis kasutama etteantud sõnu (B2). Samuti kasutatakse alates B-tasemest palju arutelusid ning osa õpetajatest rõhutab seejuures ka rääkimisteema huvitavuse olulisust (näide 49).

(49) Vaba vestlusega rühmaarutelud. Kui anda piisavalt intrigeeriv teema, mille kohta igaühel on oma tugev isiklik arvamus, tekib neil tung seda ka väljendada ning õppijad hakkavad endalegi märkamatult rääkima. (B1)

Kokkuvõttes on rääkimisoskuse arendamine keskmiselt aktiivne ja keskmiselt haarav. Kõige rohkem vestlevad õpetajad ise kogu õpperühmaga. Samuti lastakse õppijatel sageli rääkida väikestes rühmades ja paarides. Liikumise ja paaride vahetamisega seotud tegevusi laseb ópilastel teha üle poole vastanud ópetajatest. Madalamatel tasemetel õpitakse palju dialooge pähe ja luuakse neid ise, jutustatakse loetud tekste ümber ja tehakse neist kokkuvõtteid. Kõigil tasemetel tehakse rollimänge. Improvestlusi kasutavad teistest rohkem B-taseme õpetajad. B- ja C-tasemel tehakse ka debatte ning osa õpetajaid rõhutab seejuures teema huvitavuse olulisust. Küllalt suur osa rääkimisülesannetest on pärit õpikutest. Rääkimisoskuse arendamine ei ole alati jõukohane. Peaaegu pooled küsitlusele vastanud õpetajad peavad probleemiks õppijate rääkimiskartust ja hirmu vigade ees. Õpetajate hinnangul takistab õppijail rääkida ka vähene sõnavara- ja grammatikaoskus (27\% vastanuist) ning nõrgad üldoskused ja isikuomadused: introvertsus, vähene suhtlusoskus, kitsas silmaring, huumorimeele ja fantaasia vähesus, vähene enesejuhtivus. Õppijate psühholoogilisele toetamisele rääkimise ajal oskavad tähelepanu pöörata mõned õpetajad. 


\subsection{Kirjutamisoskuse arendamine}

Kirjutamisoskuse arendamiseks peamiselt kasutatavad tegevused on toodud tabelis 8 .

TABEL 8. Kirjutamisoskuse arendamiseks kasutatavad óppetegevused (osakaal vastava taseme õpetajatest, üle 50\% on märgistatud halliga)

\begin{tabular}{|l|r|r|r|r|r|}
\hline Õppetegevus & A1 & A2 & B1 & B2 & C1 \\
\hline Opikus olevad ülesanded & 100 & 77 & 73 & 100 & 14 \\
\hline Oppetaja koostatud ülesanded & 46 & 23 & 47 & 73 & 71 \\
\hline Kopeerimine & 31 & 15 & 13 & 27 & 14 \\
\hline Tarbetekstide kirjutamine & 46 & 77 & 40 & 82 & 71 \\
\hline Loovkirjutamine & 54 & 46 & 93 & 100 & 71 \\
\hline Mudelkirjutamine & 39 & 46 & 47 & 55 & 29 \\
\hline Arutluse kirjutamine & 15 & 15 & 67 & 82 & 71 \\
\hline Kiirkirjutamine & 8 & 8 & 13 & 27 & 0 \\
\hline Etteütlus & 46 & 39 & 40 & 27 & 0 \\
\hline Ümberjutustus & 31 & 31 & 60 & 55 & 29 \\
\hline
\end{tabular}

\subsubsection{Kirjutamisoskuse arendamise probleeme}

Kirjutamisoskuse arendamise sagedasema probleemina kerkib esile õppijate oskamatus lauseid moodustada ja üldse teksti luua, soov kirjutada liiga keeruliselt ning ka mõtete nappus (24\% vastajaid kõigil tasemetel, näited 50-52)

(50) A2-taseme õppijale peab andma väga konkreetseid ülesandeid, loovkirjutamisega on raske, paljud pole harjunud oma mõtteid kirjalikult väljendama. (A2)

(51) Olenevalt inimese loovusest ja "sõprusest” loovusega. Paljud ütlevad, et ma ei oska vene keeleski kirjandit kirjutada ... siis õpetadki ta vene keeles kirjandit kirjutama ja siis eesti keeles. (B2)

(52) Katse venekeelseid liitlauseid eesti keeles kirjutada. (B1) 
Teiseks teevad kirjutamise raskeks piiratud sõnavara ja puudulikud grammatikateadmised, mõnikord esitatakse õppijaile selles osas aga ka liiga kõrgeid nõudmisi (22\% vastajaid kõigil tasemetel, näited 53 ja 54).

(53) Eksimused vormide moodustamisel ja ühildumise ning rektsiooni kasutamisel. (A1)

(54) Rektsioon; sihitise kasutamine; venepärase stiili kasutamine loovtöös. (C1)

Üks õpetaja näeb probleemi ka endas (55).

(55) Suurim probleem on vast õige ülesandepüstitus? Nii et suurim probleem on mul iseendaga. (A1)

Kirjutamisoskuse arendamise kolmas probleem on selle ajamahukus (15\% vastajaid). Kirjutamine ise võtab palju aega, mistõttu antakse see tihti kodutööks, ja kirjalikele töödele tagasiside andmine võtab ka palju aega. Kui õppijad kirjutavad kodus, siis võib olla probleemiks, et nad ei tee oma tööd ise ja et raskuste korral ei saa nad vajalikku abi. Madalamatel tasemetel valmistab õpetajatele mõnikord raskusi lisaks ka vigade parandamine (näide 56).

(56) Ka igaühele eraldi tagasiside andmine kirjutatu kohta on aeganõudev, eriti algtasemel ja natuke pikemate tekstide puhul, sest vigu esineb väga palju ja sageli sellistes asjades, mida ei peagi veel teadma. Minult nõuab mõttepingutust, milliseid vigu on oluline parandada ja milliseid mitte, ja kuidas parandusi selliselt esitada, et need õppijale rõhuvalt ei mõjuks. (A1)

\subsubsection{Kirjutamisoskuse arendamise häid kogemusi}

Arvatakse, et kirjutada tuleb igal juhul palju ja seejuures endale huvitavatel teemadel. Positiivse mõjuga on olnud ühiskirjutamine ja ühine analüüs (näited 57 ja 58).

(57) Õppijatele on meeldinud sellised koduülesanded, kus tuleb näiteks ühisesse Google’i dokumenti kirjutada probleeme või küsimusi ja siis 
teiste probleemidele erinevaid vastuseid või lahendusi või soovitusi pakkuda. See tekitab hasarti, sest õppijad saavad kirjutada oma tegeliku eluga seotud küsimustest, ja ühtlasi saavad kaasõppijatelt elulist tagasisidet ning teistele õppijatele oma soovitusi pakkuda. Ja selline Google'i dokument on pärast ka tunnis väga huvitav arutelumaterjal. (A1)

(58) Koos kirjutamine - õpetaja tahvlile või Wordi ja õppijad genereerivad ideid, mida ja kuidas kirjutada. Hiljem analoogne ülesanne iseseisvaks lahendamiseks kodus. (B2)

Kirjutamisoskuse arendamisel on õpetajate arvates andnud häid tulemusi ka mudelkirjutamine etteantud näidiste järgi ning eri osaoskuste ühendamine kirjutamisülesandega. Mõne õpetaja arvates on kasulikud õpikuteksti ümberjutustused, etteütlused ja tõlkeharjutused ning küsimustele vastamine. Eraldi tuuakse esile aktiivsete ülesannete (näide 59) head mõju.

(59) Õppijate aktiivsus tagasiside andmisel, ühiselt millegi kirjutamine, omavahel seotud voorude kirjutamine (nt sõnumivahetus, kus tuleb kokku leppida ühine väljasõit, kink ühisele sõbrale vms). (A2)

C1-tasemel tuuakse välja kindla sõnavara kasutamist tekstis ning põhjaliku tagasiside andmist ja selle järgi teksti ümberkirjutamist.

Kokkuvõttes on kirjutamisoskuse arendamine keskmiselt aktiivne. Kõige rohkem lastakse õppijail täita õpikus olevaid kirjutamisülesandeid. Küllalt palju tehakse loovkirjutamise ülesandeid, kirjutatakse tarbetekste ning B- ja C-tasemel ka arutlusi. Osa õpetajaid pooldab kirjutamise ühendamist teiste osaoskustega, mis muudab kirjutamise aktiivsemaks. Teine osa õpetajaid kasutab aga passiivsemat tüüpi ülesandeid, nagu ümberjutustused, etteütlused ja tõlkeharjutused. Haaravusest räägitakse kirjutamisoskuse arendamisega seoses suhteliselt vähe. Õpetajate sõnul tekitab õppijais aga hasarti, kui nad saavad ühiskirjutamise käigus reageerida end tegelikult huvitavatele küsimustele või tegelikele probleemidele. Kirjutamisoskuse arendamine ei ole alati jõukohane. Õpetajate väitel ei oska õppijad sageli lauseid moodustada ja teksti üles 
ehitada, samuti napib neil mõtteid ja püütakse kirjutada liiga keeruliselt. Õpetajate arvates takistab kirjutamist õppijate puudulik sõnavara ja napid grammatikateadmised, kuid vahel esitavad õppijatele vastavast tasemest kõrgemaid nõudeid ka õpetajad. Etteantud näidiste järgi kirjutamist peab kasulikuks palju õpetajaid. Kõrgematel tasemetel rõhutatakse ka tagasiside saamise olulisust teksti arendamisel.

\section{Järeldused ja kokkuvõte}

Eesti keele kui teise keele täiskasvanute kursustel kasutatakse küllaltki mitmesuguseid õppetegevusi kõigi osaoskuste, grammatika ja sõnavara arendamiseks. Õpetajad esitavad ka palju huvitavaid ülesandeid, mis on nende kogemuste põhjal olnud õppetöös tõhusad. Samas toovad õpetajad aga ka välja hulga probleeme, mis õppijatel eesti keelt õppida takistavad.

Vastuste analüüsi tulemusena võib öelda, et kõige rohkem arenguruumi on täiskasvanute eesti keele kursustel õppetöö jõukohasuse osas. Lugemis- ja kuulamistekstidest arusaamist takistab õpetajate arvates õppijate napp sõnavara, soov mõista teksti sõna-sõnalt ning kuulamise puhul ka liigne ärevus. Grammatika õppimise probleemidena nähakse grammatika erinevust õppijate emakeele grammatikast, õpitud grammatika mittejõudmist õppijate keelekasutusse ja sellest tulenevaid korduvaid vigu, õppijate väheseid terminoloogiateadmisi, eri õppijate erisugust vajadust grammatikaõppe järele ning osa õppijate hirmu grammatika ees. Ka kirjutamine ei ole õppijaile alati jõukohane, põhjusteks napp sõnavara ja vähesed grammatikateadmised, oskamatus teksti üles ehitada ning soov kirjutada liiga keeruliselt.

Kõige rohkem probleeme jõukohasusega on sõnavara ja rääkimise arendamisel, need toob esile ligi pool vastanud õpetajatest. Sõnavara põhiprobleemiks on sõnade halb meeldejäämine, mille põhjuseks peetakse õppijate kehva mälu, vähest iseseisvat õppimist ja oskamatust sõnu kontekstiga seostada. Õpetajad mainivad ka eesti keele sõnade erilist keerukust, näiteks vajadust õppida iga sõna ära kolmes vormis. Rääkimise 
peamiseks probleemiks on hirm: õppijad kardavad rääkida ja kardavad teha vigu. Rääkimist takistab õpetajate meelest ka õppijate vähene sõnavara ja grammatikateadmised ning nõrgad üldoskused - vähene suhtlusoskus, kitsas silmaring, introvertsus, huumorimeele ja fantaasia puudus ning madal enesejuhtivus. Seega on õppetöö jõukohasuse probleemide põhjused õpetajate arvates peamiselt õppijais endis. Lisaks on õpetajate hinnangul puudusi ka õppematerjalides: seal napib häid tekste, eriti kuulamistekste ning grammatika õpetamine ei ole alati piisavalt hästi läbi mõeldud.

Kui õppetöö jõukohasusega on nii palju probleeme, võib siiski teha järelduse, et probleemid ei ole vaid õppijais, vaid arendada on vaja nii õppesisu ja õppetegevusi kui ka tunni ülesehitust. Õppetöö on õppijaile jõukohane siis, kui arvestatakse eesti keele kui teise keele oskuse loomulikku arengurada. Selleks peab õpetaja teadma, kui keerukas keelekasutus on vastaval tasemel olevaile õppijaile arusaadav ja kui keerukat, täpset ja sujuvat keelt suudavad óppijad ise kasutada. Õpetajal peavad olema ka teadmised eksplitsiitse ehk seletuspõhise ja implitsiitse ehk alateadliku õppe mõistliku vahekorra kohta keeleõppes. Samuti peab õpetaja mõistma keelestruktuuride arengumehhanisme, näiteks teadma, et õppija peab saama keerukamaid keelestruktuure enda loodud tekstides piisavalt kasutada, enne kui need täpseks ja automaatseks muutuvad. Õpetajate vastustest on näha, et nad ootavad õppijailt kohati ka mittetasemekohaste keelestruktuuride üsna korrektset kasutust, mis võib pidurdada õppijate keelekasutuse katsetusi.

Arvestada tuleb ka õppimisprotsessi kui terviku loomulikku arengurada. Suur osa õpetajaid ei pühenda kursustel aega ópioskuste ja õpistrateegiate arendamisele. Näiteks tekstimõistmise strateegiaid õpetatakse peamiselt vaid kõrgematel tasemetel ja ka seal ei tee seda kaugeltki kõik õpetajad. Tõhusal keelekursusel peab õpetaja lähtuma õppijate keelelistest ja üldistest oskustest ning aitama neil sealt sobivas tempos edasi liikuda. Õppijaid saab toetada õppematerjalide ja tegevuste sobiva valiku ja järjestusega, näiteks valmistades nõudlikumate ülesannete täitmist ette vajalikke keelendeid, õpistrateegiaid ja osaoskuste alaoskusi 
õpetavate harjutustega. Samuti on väga oluline õppijatele piisava iseseisvuse andmine, neid samas õigel ajal ja parajal määral toetades. Keeleõppes on põimunud lingvistilised ja psühholoogilised protsessid, kuid oppijate psühholoogilise toetamise vajalikkuse oskavad välja tuua vaid mõned õpetajad. Seega tuleb senisest palju suuremat tähelepanu pöörata psühholoogiliselt turvalise, rõõmsa ja energilise õpiõhkkonna loomisele, sest ainult siis, kui õppijad tunnevad ennast tunnis hästi ja neil on energiat, saavad nad ennast avada ja suudavad toime tulla uue keele õppimise väljakutsetega.

Arenguruumi on kursustel ka õppetöö aktiivsuse osas. Küllaltki palju kasutatakse traditsioonilisi ja mitte eriti aktiivseid õppetegevusi, mis nõuavad tekstist info leidmist, küsimustele vastamist, grammatika ja sõnavara seletamist, kirjalike harjutuste täitmist, sõnade õppimist, vestlemist õpetaja ja kogu õpperühma vahel, ümberjutustuste kirjutamist jmt. Samas kasutab suur osa õpetajaid enda sõnul ka küllalt palju aktiivõppemeetodeid, näiteks mängustatud ülesandeid, vestlusi paarides ja väikestes rühmades koos liikumise ja vestluskaaslaste vahetamisega, rollimänge, debatte, loovkirjutamist jm. Häid kogemusi kirjeldades esitatakse mitmeid kasulikke ja toredaid ülesandeideid.

Probleemid osaoskuste, grammatika ja sõnavara arenemisega näitavad aga, et autentset sisendit ja aktiivseid õppetegevusi on vaja kasutada rohkem ning need peavad olema paremini läbi mõeldud. Aktiivsed óppetegevused peavad moodustama suurema osa tunnist, vastama täpselt õppe-eesmärkidele ning olema teadlikult järjestatud kergemalt keerukamateni, toetatutelt vaba keelekasutust nõudvamateni. Paarisja väikerühmades tehtavad eri tüüpi ülesanded ja harjutused, milles õppijad räägivad korraga, peaksid moodustama suurema osa tunnist, ja õpetaja seletused ning kogu õpperühmaga koos tehtavad ülesanded väiksema osa. Kokkuvõttes peab iga õppija saama keeletunnis võimalikult palju keelelist sisendit ja proovida ise võimalikult palju keelt suhtluseesmärkide saavutamiseks kasutada.

Õppeteemade, -tekstide ja -ülesannete haaravuse teema ei kerki õpetajate vastustest palju esile. Osa õpetajaid nimetab õppetekstide 
huvitavuse vajalikkust ning nende jaoks on probleem, kui õpikutekstid alati sellised ei ole. Sel juhul püütakse kohati tekste ka ise lisainfo vmt huvitavamaks muuta. Samuti mainib osa õpetajaid rääkimis- ja kirjutamisülesannete teema huvitavuse ning tähenduslikkuse tähtsust õppijate käivitamisel. Õpetajate vastustest ilmneb kohati ka loovate, improvisatsiooniliste ja aktiivsete ühistegevuste positiivne mõju õppijate tegevusse haaramisel. Mitme õpetaja hinnangul on õppijaile haarav ka grammatikaga tegelemine.

Haaravus on tõhusa õppetöö oluline omadus, kuid õpetajate vastustest jääb siiski mulje, et see ei ole praegu õppetöö läbiviimisel kõige olulisem. Kasutatakse küllalt palju õpikutekste ja ülesandeid ning eksamitüüpi ülesandeid, mis ei ole alati väga haaravad, sest ei sisalda uudset infot, ei paku põnevust ja intriigi ning võimalusi tugevate emotsioonide tundmiseks. Aktiivõppeülesanded, sh eriti mängustatud-improvisatsioonilised ülesanded on potentsiaalselt väga haaravad, kuid nende haaravus sõltub suurel määral ülesannete läbiviimise oskuslikkusest: rühmatunde ja õpiõhkkonna loomisest, õppijate oskuslikust käivitamisest, ülesannete sobivast valikust ja järjestusest, ülesannete parajast raskusastmest ja rühma targast juhtimisest.

Kokkuvõttes on eesti keele kui teise keele täiskasvanute kursuste õppemetoodikal päris palju arenguruumi nii õppetöö jõukohasuse kui ka aktiivsuse ja haaravuse osas. Edasiliikumiseks on vaja arendada nii õpetajate esmast väljaõpet kui ka täiendusõpet. Kõigil õpetajatel peavad esiteks olema süsteemsed tänapäevased teadmised eesti keele kui teise keele oskuse loomulikust arengurajast ja keeleoskuse arenemise põhimõtetest. Teiseks peavad ópetajad valdama suurt hulka tänapäevaseid aktiivõppemeetodeid ning oskama neid keeletunnis õigel ajal ja õigel viisil kasutada. Kolmandaks peavad õpetajatel olema teoreetilised teadmised õppimisprotsessist ja rühmajuhtimisest ning ka praktilised oskused neid teadmisi rakendada. Samadest põhimõtetest lähtuvalt on vaja arendada ka õppematerjale, sest neil on õppetegevustele suur mõju. Õppemetoodika uurimist ja arendamist on kindlasti samuti vaja jätkata. Selle küsitluse vastused iseloomustavad óppemetoodikat vaid aktiivsemate ja 
õppetöö arendamisest huvitatumate õpetajate vaatenurgast. Edaspidi on vaja viia läbi tunnivaatlusi ning uurida õppijate keeleoskuse arenemise ja eesti keele õppesse suhtumise seoseid kursustel kasutatavate õppetegevustega.

\section{Kirjandus}

APA Dictionary of Psychology. https://dictionary.apa.org (19.2.2021).

Brophy, Jere 2016. Kuidas õpilasi motiveerida. Käsiraamat õpetajatele ['Motivating Students to Learn']. Tallinn: Archimedes.

CEFR = Euroopa keeleõppe raamdokument. Õppimine, õpetamine ja hindamine ['Common European Framework of Reference for Languages: Learning, Teaching, Assessment']. Tartu: Haridus- ja Teadusministeerium, 2007.

Demirezen, Mehmet 2011. The foundations of the communicative approach and three of its applications. - Journal of Language and Linguistic Studies 7 (1), $57-71$.

Dewaele, Jean-Marc 2005. Investigating the psychological and the emotional dimensions in instructed language learning: Obstacles and possibilities. The Modern Language Journal 89 (3), 367-380. https://doi.org/10.1111/ j.1540-4781.2005.00311.x

Dewaele, Jean-Marc 2015. On emotions in foreign language learning and use. JALT 2015 Conference Article. The Language Teacher 39 (3), 13-15. https://doi.org/10.37546/JALTTLT39.3-3

Dörnyei, Zoltán 1994. Motivation and motivating in the foreign language classroom. - The Modern Language Journal 78 (3), 273-284. https://doi. org/10.1111/j.1540-4781.1994.tb02042.x

Dörnyei, Zoltán, Tim Murphey 2003. Group Dynamics in the Language Classroom. Cambridge Language Teaching Library. Cambridge: Cambridge University Press. https://doi.org/10.1017/CBO9780511667138

Eesti keele majad ['Estonian Language Houses']. https://www.integratsioon.ee/ eesti-keele-majad (26.2.2021).

Eesti keele tasemeeksamid ['Estonian Language Proficiency Examinations']. https://www.innove.ee/eksamid-ja-testid/eesti-keele-tasemeeksamid/ (26.2.2021).

Eksamistatistika ['Statistics of the Examinations']. https://www.innove.ee/wpcontent/uploads/2020/12/EK_Statistika_2020.pdf (26.2.2021).

Ellis, Nick C. 2003. Constructions, chunking and connectionism: The emergence of second language structure. - C. J. Doughty, M. H. Long (eds.). The 
Handbook of Second Language Acquisition. Oxford: Blackwell Publishing, 63-103.

Gardner, Robert C. 2007. Motivation and Second Language Acquisition. - Porta Linguarum 8, 9-20.

Hadfield, Jill 2010. Rühmadünaamika võõrkeeletunnis ['Classroom Dynamics']. Tallinn: Argo.

Harmer, Jeremy 2007. How to Teach English. Harlow: Pearson Education Ltd.

Housen, Alex, Folkert Kuiken, Ineke Vedder 2012. Complexity, accuracy and fluency. Definitions, measurement and research. - A. Housen, F. Kuiken, I. Vedder (eds.). Dimensions of L2 Performance and Proficiency: Complexity, Accuracy and Fluency in SLA. Language Learning \& Language Teaching 32. Amsterdam \& Philadelphia: John Benjamins, 1-20. https:// doi.org/10.1075/1llt.32.01hou

INSA 2020. Integratsiooni Sihtasutuse aastaraamat 2019. https://www.integratsioon.ee/sites/default/files/insa_aastaraamat_2019.pdf (26.2.2021).

Karm, Mari 2013. Õppemeetodid kõrgkoolis ['Teaching Methods in Higher Education']. Tallinn: SA Archimedes. http://www.digar.ee/id/nlib-digar:121275

Keeleamet. https://www.keeleamet.ee/et (26.2.2021).

Kikas, Eve, Aaro Toomela (toim.) 2015. Õppimine ja õpetamine kolmandas kooliastmes. Üldpädevused ja nende arendamine ['Learning and Teaching in the Third Stage. General Competences and Their Development']. Tallinn: Eesti Ülikoolide Kirjastus.

Kitsnik, Mare 2008. Eesti keele õppekomplekt B1, B2 ['Estonian Language Learning kit for B1, B2']. Tallinn: Ilo

Kitsnik, Mare 2018. Iga asi omal ajal: eesti keele B1- ja B2-taseme verbikonstruktsioonid keeleoskuse arengu näitajana ['All in Good Time: Estonian B1and B2-level Verbal Constructions as Indicators of the Development of Language Proficiency']. Dissertations on Humanities 43. Tallinn: Tallinna Ülikool.

Kitsnik, Mare 2019. Eesti keele kui teise keele õppimine - kas raske töö või kerge lõbu? ['Learning Estonian as a second language - hard work or easy fun?'] - Keel ja Kirjandus 1-2, 39-57.

Kitsnik, Mare 2020. Eesti keele kui teise keele õppematerjalide koostamise ja hindamise juhend ['Guidelines for the Preparation and Assessment of Teaching Materials for Estonian as a Second Language']. RITA-Ränne projekt. https://sisu.ut.ee/sites/default/files/ranne/files/oppem_koostamise_ juhend.pdf (26.2.2021). 
ÕPPETEGEVUSTE HAARAVUS, AKTIIVSUS JA JÕUKOHASUS ...

Kitsnik, Mare, Jelena Berezina 2021. Kas on olemas vähemotiveeritud ja nõrku õpperühmi? Mängustatud õppe mõjust õpilaste eesti keele kui teise keele kasutamisele kolmanda klassi näitel ['The effect of gamified learning on the use of Estonian as a second language by third grade pupils']. - Eesti Rakenduslingvistika aastaraamat 17.

Kitsnik, Mare, Pirgita-Maarja Hallas 2020. Mängustatud õppetegevuste mõju üheksanda klassi õpilaste suhtumisele eesti keele kui teise keele tundidesse ['The effect of gamified learning activities on the attitudes of 9th grade pupils towards lessons of Estonian as a second language']. - Eesti Rakenduslingvistika aastaraamat 16, 77-94. https://doi.org/10.5128/ERYa16.05

Kitsnik, Mare, Leelo Kingisepp 2006. Naljaga pooleks ['Estonian Language Learning Kit for Elementary Level']. Tallinn: Iduleht.

Krull, Edgar 2018. Pedagoogilise psühholoogia käsiraamat ['Handbook of Pedagogical Psychology']. Tartu: Tartu Ülikooli Kirjastus.

Kärtner, Piret 2000a. Lugemisoskuse arendamine. Keeleõpetaja metoodikavihik ['Developing Reading Skills']. Tallinn: Tea kirjastus.

Kärtner, Piret 2000b. Kuulamisoskuse arendamine. Keeleõpetaja metoodikavihik ['Developing Listening Skills']. Tallinn: Tea kirjastus.

Kärtner, Piret 2000c. Kõnelemisoskuse arendamine. Keeleõpetaja metoodikavihik ['Developing Writing Skills']. Tallinn: Tea kirjastus.

Larsen-Freeman, Diane 2007. Techniques and Principles in Language Teaching. Oxford: Oxford University Press.

Mangus, Inga, Merge Simmul 2009. Tere ['Estonian for Beginners 0-A1']. Tallinn: Kirjatark.

Mangus, Inga, Merge Simmul 2016. Tere jälle ['Textbook of Estonian A1-A2 (B1)']. Tallinn: Kirjatark.

Mangus, Inga, Merge Simmul 2020. Tere ['Estonian for Beginners 0-A1']. Tallinn: Kirjatark.

Nordin, Razanawati, Lin Siew Eng 2017. Text-selection for teaching reading to esl tertiary students: A study on genre and content preferences. - International Journal of Instruction 10 (1), 71-84. https://doi.org/10.12973/ iji.2017.1015a

Pesti, Mall 2016. E nagu Eesti ['Estonian Textbook for Beginners']. Tallinn: KiriMari Kirjastus.

Pesti, Mall 2018. K nagu Kihnu ['Estonian Textbook for B2']. Tallinn: Kiri-Mari Kirjastus.

Richards, Jack C. 2006. Communicative Language Teaching Today. Cambridge: University Press. 
Saar Poll 2013. Keeleõppe arendamise programmide mõju uuring ['Study on the impact of language learning development programs']. Tellija: Integratsiooni ja Migratsiooni Sihtasutus Meie Inimesed. Tallinn. http://hdl.handle.net/10062/40695

Sõnaveeb. https://sonaveeb.ee/ (19.2.2021).

Thornbury, Scott 2002. How to Teach Vocabulary. Harlow: Longman.

Thornbury, Scott 2019. Learning Language in Chunks. Part of the Cambridge Papers in ELT series. Cambridge: Cambridge University Press. https:// www.cambridge.org/elt/blog/wp-content/uploads/2019/10/LearningLanguage-in-Chunks.pdf (19.2.2021).

Tomlinson, Brian 2010. Engaged to learn ways of engaging ESL learners. Advances in Language and Literary Studies 1 (1), 29-55. https://doi. org/10.7575/aiac.alls.v.1n.1p.29

Tomlinson, Brian 2012. Materials development for language learning and teaching. - Language Teaching 45 (2), 143-179. https://doi.org/10.1017/ S0261444811000528

Tomlinson, Brian (ed.) 2013. Developing Materials for Language Teaching. Bloomsbury.

Vallimäe, Tanel, Triin Roosalu, Epp Kallaste, Aivar Joorik 2018. Eesti keelest erineva emakeelega täiskasvanute eesti keele õpe lõimumis- ja tööhõivepoliitikas: kvaliteet, mõju ja korraldus ['Estonian language learning in integration and employment policy']. 3. osa uuringust "Keeleõppe pakkujate analüüs". Tallinn: Centar, Tallinna Ülikool. 


\title{
Engagement, activity and affordability of learning activities in Estonian as a second language courses for adult learners: Analysis of teachers' opinions
}

\author{
MARE KITSNIK, KATRIN MIKK \\ University of Tartu
}

Estonian as a second language is mostly taught to adults in language courses. The courses are very popular among the target group, but the effectiveness of the courses is not always very high: a large part of those who have passed the course are unable to take the necessary language exam or use Estonian outside the classroom (Saar Poll 2013, Eksamistatistika). The effectiveness of learning a second language depends on many factors, one of which is the teaching methodology used. Today, it is considered that there is no universal methodology, but effectiveness is ensured by the engagement, activity and affordability of learning activities for the target group (Dörnyei 1994; Richards 2006; Brophy 2016; Tomlinson 2010, 2012; Kitsnik 2020).

The methodology used in teaching Estonian as a second language for adult learners has not been scientifically researched so far. This article focuses on teachers' assessment of the teaching activities used in their lessons. In order to obtain survey data, a survey was conducted among training companies approved by Keeleamet (the Language Board), Estonian language houses and teachers of the adaptation program. 59 teachers responded to the survey, $61 \%$ of whom have more than 10 years of teaching experience. The survey consisted of 35 questions (both multiple-choice and open-ended) on learning activities, problems and good practices used to develop listening, reading, speaking, writing, vocabulary and grammar skills.

In their opinion, teachers use quite authentic teaching materials, and different learning activities (Larsen-Freeman 2007). According to teachers, almost all of them who responded to the survey at least sometimes use gamification. The main problems were students' fear of speaking Estonian (mentioned by $46 \%$ of respondents) and poor memorization of new words by students (also $46 \%$ 
of respondents). In addition the common problems were a shortage of good teaching texts (especially listening texts), the ambiguity of the volume of teaching grammar, the students' insufficient learning habits and learning strategies, and the lack of language practice outside of lessons. The descriptions of good practices highlighted the importance of the interest and informativeness of the study texts and the usefulness of the activity, creativity, diversity and systematic nature of the tasks.

The problems that have emerged point to the need to develop teaching methods for adult Estonian language courses. As follows, there would be a need for lesson surveys, student surveys and testing to obtain more detailed information on the impact of the content and format of learning activities from sources other than teachers. It would then be worthwhile experimenting with interventions in mainstream learning activities through a systematic curriculum based on modern language learning principles and successful experiences to date, focusing on finding solutions to the main problems that have arisen.

Keywords: second language learning; learning activities; language courses; engagement; activity; affordability; Estonian language

\section{Mare Kitsnik}

Tartu Ülikooli eesti ja üldkeeleteaduse instituut Jakobi 2, 51005 Tartu, Estonia

mare.kitsnik@ut.ee

\section{Katrin Mikk}

Tartu Ülikooli eesti ja üldkeeleteaduse instituut

Jakobi 2, 51005 Tartu, Estonia

katrin.mikk@ut.ee 